\title{
How Funding of Non-profit Social Organizations Affects the Number of Volunteers
}

\author{
Clausen, Mads Roke
}

Published in:

Voluntas

DOI:

10.1007/s11266-021-00321-1

Publication date:

2022

Document Version

Peer reviewed version

Citation for published version (APA):

Clausen, M. R. (2022). How Funding of Non-profit Social Organizations Affects the Number of Volunteers. Voluntas, 33(2), 362-373. https://doi.org/10.1007/s11266-021-00321-1

\section{General rights}

Copyright and moral rights for the publications made accessible in the public portal are retained by the authors and/or other copyright owners and it is a condition of accessing publications that users recognise and abide by the legal requirements associated with these rights.

- Users may download and print one copy of any publication from the public portal for the purpose of private study or research.

- You may not further distribute the material or use it for any profit-making activity or commercial gain.

- You may freely distribute the URL identifying the publication in the public portal.

Take down policy

If you believe that this document breaches copyright please contact rucforsk@kb.dk providing details, and we will remove access to the work immediately and investigate your claim. 


\title{
How the funding of non-profit social organizations affects the number of volunteers
}

\begin{abstract}
In recent decades, significant changes have occurred to how charities and non-profit organizations are funded. However, only limited research has considered how the new financial landscape affects the work being carried out by these organizations. This article presents a quantitative analysis of the relationship between financing and the number of volunteers. The data material consists of panel data on revenue streams to nationwide, social, non-profit organizations in Denmark. The analysis reveals that a strong, positive relationship between both value-driven general revenues and the organizations' equity in relation to the number of volunteers. Conversely, targeted and means-driven investments do not have any significant correlation with the number of volunteers.

Overall, the findings point to the fact that more volunteers can be attracted through forms of financing that strengthen the stability and organizational capacity of an organization as well as its ability to independently organize the work to be done.
\end{abstract}

Key Words: Social finance, volunteers, non-profit, social investment, organizational capacity 


\section{Introduction}

Social non-profit organizations play a major role for many people: They establish communities for lonely young people; they provide services and create coercion-free space for those on the fringes of society; and they act as the voice for vulnerable individuals who are struggling to have their voices been heard (Boje 2017). Just to name a few examples.

On the global stage, there have been significant changes in the funding of social non-profit organizations over the past 10-20 years. This development is caused by two different trends. First, the non-profit organizations have increasingly taken over functions that have previously been performed by the public sector (Frumkin and Kim 2002; Milbourne 2013; Smith 2018). Second, foundations and investors have shifted strategies, now increasingly using focused investments and new instruments (e.g. social impact bonds) instead of more general donations (Salway 2017; Pharoah 2012). This development has been particularly noticeable in England, where there has been a significant shift in the financing of many charities. This has meant that more than $80 \%$ of all public funding is now channelled via specific contracts tendered on competitive terms rather than through general grants to organizations (Nicholls et al. 2015). Simultaneously, new markets and new financial instruments have emerged that potentially allow organizations to attract more capital (Salway 2017).

The consequences of this development have yet to be seen and require further scrutiny. Some organizations have won many tenders, have therefore been able to scale up their efforts, and now find themselves able to help more people. At the same time, numerous studies have shown how fierce competition has led to survivalism among these organizations and a lack of solidarity in the voluntary sector. This development has radically transformed the ethos of the voluntary 
organizations from being independent providers of assistance and social policy watchdogs to being cheap service providers, who are unable to voice criticism or exert influence (Murray 2017). Similarly, numerous studies have found increasing transactions costs in the organizations due to the need for larger, more professional secretariats to draft applications and to carry out the internal monitoring of project activities (Milbourne 2013; Mulgan 2015).

While the developments in Denmark have been less pronounced than in England, there is also clear Danish evidence that government and private foundations are increasingly focusing on service provision and, at the same time, increased requirements have been implemented for documentation and impact assessments (Espersen et al. 2018). This has contributed to an isomorphic pressure on the organizations in relation to targeting and professionalizing their efforts (Andersen 2019) which might weaken the flexible elements of volunteering, and thereby contribute to a reduction of the number of volunteers (Henriksen et al. 2008). This development makes it relevant to investigating the possible connections between financing the volunteer activities and the number of volunteers in the Danish context.

On this background, the article addresses the following question:

Is there an association between the different forms of financing and the number of volunteers in nationwide social non-profit organizations in Denmark?

The research question has been restricted focusing exclusively on the nationwide Danish social nonprofit organizations and includes neither local, regional nor informal social movements and networks. The analysis builds on a panel data set with nationwide social non-profit organizations in the social field. 
One of the challenges when studying financing in the non-profit sector is that the number of financial instruments is numerous and constantly growing. To filter out the 'noise' created by the many instruments, a generic model developed by Nicholls (2010) has been applied, which incorporates the rationalities behind the investments. Based on Weber (1978), Nicholls has developed a model that identifies three investment rationalities (means-driven, value-driven and systemic) based on two different subjective decision-making criteria (zweckrational and wertrational). The significance of the investment rationalities is investigated using a regression analysis and compared, on the one hand, with a model in which funding is calculated according to a mix of public and private sources and, on the other, with a model considering the age and equity of the organizations. Nicholl's model and the main theoretical positions he uses to describe the financing of social non-profit organizations and its impact on the number of volunteers is outlined in section 2 .

The third section accounts for the data and method, including the choice of regression model. Section 4 presents the main lines in the development of the Danish social non-profit sector to provide the international reader with the prerequisites to interpret the results. Section 5 presents the findings and section 6 discusses the results and possible implications for further research.

\section{Analysis of the relationship between financing and the number of volunteers in non-profit organizations}

To be clear: The perceptions concerning the extent and the consequences of the financial changes for the non-profit organizations are highly contested. One of the less worried voices can be found in Kramer's (1994) new classic, Contract Culture: Dream or Nightmare. Here, the argument is that 
de-voluntarization as a result of increased bureaucratization, formalization and professionalization is based on a myth regarding the existence of a golden age of voluntarism in which "small, informal community-based organizations were able to rely on contributions and volunteers to provide personal social services" (ibid. p. 52). In Kramer's view, increased bureaucratization is a natural consequence of modernization and in no way a contradiction to either flexibility or efficiency. The subsequent organizational consequences, including collaboration with volunteers, are not predetermined, but rather subject to leadership decisions and actions (Bernstein 1991).

More recent studies, however, indicate that the increased bureaucratization of the non-profit organizations results from increased regulation as well as more formal requirements for processes and working methods (Grønbjerg 1991; Warburton et al. 2018; Baines et al. 2011; Frumkin and Kim 2002). Furthermore,this has created a development towards an isomorphic transformation that again has changed the ethos of the organizations from informal and often smaller organizations to larger, more formalized organizations (Milbourne og Murray 2017; Aiken and Harries 2017).

The changes in the financial landscape of non-profit organizations vary from country to country, depending on the welfare regime and welfare mix. England is a particularly interesting case in this regard. First, because London is a global centre for the development and sale of commercial financial services, which has had a spill over effect on the development and implementation of new financial instruments for the funding of social efforts - including the third sector (Mulgan 2015). Second, because voluntary social organizations since the Thatcher government took office in 1979 have played an ever-increasing role in the production of welfare services. This development accelerated under the Blair governments, where voluntary social organizations were seen as a strategic lever that could increase the supply of service providers. This development involved 
extensive capacity-building aimed at increasing the number of organizations that could compete for public service contracts (Alcock 2016). An additional reform of the financing through service contracts took place under the Cameron governments in connection to the 'Big Society' vision. These complex of reforms entailed a marked increase in the competition for service contracts. They changed the financial landscape to such an extent that the restructuring in a scientific sense can be considered a one-to-one stress test of the sector enabling an analysis of the strategic reactions of the organizations to the new conditions (Ishkanian and Szreter 2012).

There is a considerable amount of research investigating the English case that expresses a critical perspective on the neo-liberal context behind the current trends in the financing of social non-profit organizations. The increased English use of competition for funding, spread of a contract culture and erosion of the advocacy role of the voluntary sector are thus viewed as a neo-liberal ideological impact (Whitfield 2014; Ishkanian and Szreter 2012; Murray and Milbourne 2017). Here, it is argued that the impact of the financial restructuring that resulted from the 'Big Society' programme has been increased competition, which has led to survival among the organizations. This has again favoured the larger organizations due to their access to capital and their organizational capacity to carry out lobbying aimed at obtaining service assignments and to prepare professional tender materials (Clifford et al. 2013; Body 2015; Aiken and Harris 2017).

Within this critical perspective, two distinct tendencies can be found concerning how the funding affects the number of volunteers in these organizations. On the one hand, there are examples of how the increased competition for financial resources in a market without quality standards has resulted in more volunteers. This because some organizations, in the competition to win the service contracts on offer, pursue a cost-leadership strategy; that is, they reduce their expenses as much as 
possible to obtain service contracts by making the cheapest bid. This has led to a 'deprofessionalization' of the organizations, as expensive specialists (e.g. psychologists) have been replaced with trained volunteers. In these cases, the increased 'marketization' of the financing has led to the increased use of volunteers and the deterioration of welfare services (Body 2015; Murray 2017).

On the other hand, it is argued that the contract culture and demands from investors have forced the organizations to deviate from their original ethos and the principles about 'voluntary action and individual care' (Milbourne 2013; Alcock 2016; Murray 2017). The contract culture has contributed to the isomerization of the organizations, and volunteers have become a risk factor, as they are more difficult to manage and therefore, have rendered the provision of specific services more difficult. Overall, this has led to fewer volunteers.

There is a lot of valuable learning from the above research on the consequences of changes in the relationship between the financing of non-profit organizations and the work they are carrying out. At the same time, however, from a research perspective, it is problematic that the concepts used in analyses of the development in the organizational revenues are general and unclear. This problem applies especially to analyses in which the state revenue is understood as a single category (Frumkin and Kim 2002; Salamon 2010). Doing so does not account for the considerable variations often found in public revenue sources, for example, between donations and sales of services. Similarly, private sources of income can be based on both contracting and traditional charitable giving. Some of the English research and the related criticism of the neo-liberal elements of the current financing is based on very general analyses of revenue streams, which limit the possibilities of examining whether different types of financial instruments affect the relationship between paid 
labour and voluntary efforts (Milbourne and Murray 2017; Whitfield 2014; Ishkanian and Szreter 2012). An ideal analysis must be based on precise concepts that can distinguish between different types of financing instruments and their rationalities.

A research-based overview of the financial instruments used to support social causes can be found in the relatively nascent research area, social finance, which deals with the allocation of capital to social and environmental purposes (Nicholls 2015; Young 2015). The social finance perspective is instrumental in relation to the question addressed in this article. It provides an overview of the full range of financial instruments, from general grants (e.g., government grants) and philanthropic donations to more targeted market investments aimed at generating profit, where social objectives are the secondary goal. It also covers a variety of hybrid models, which includes forms of borrowing and investment, such as social impact bonds (Nicholls and Emerson 2015).

However, the field is limited when it comes to distinguishing between various rationalities among the investors and how they affect the social organizations. But ignoring these various rationalities and focusing only on cash flows and risk distribution from different sources will result in superficial analyses that neglect the differences that the various investment rationalities will have for the receiving organizations and for the entire social sector. It is against this background that Nicholls (2010) attempts to develop a theoretical model for social financing that captures the diversity and underlying rationalities. Based on Weber (1978), he constructs a model on the assumption of two different subjective criteria for decision-making: means-driven (zweckrational) and value-driven (wertrational). 
In Nicholl's interpretation, means-ends-driven investments are aimed at maximizing the financial return to the owners of the capital, but they also include social investment 'that does not focus on the financial returns to the investor, but, rather, takes a business-like approach to grant making that endeavours to maximize "soft" returns' (ibid. p. 80). The definition of this rationale further implies that 'the capital is supposed to be effective according to the investors' set of outcome objectives' (ibid., p. 80), which changes the institutional logic from philanthropy to investment. An example of this type of revenue is the sale of specific services.

According to Nicholl, value-driven social investments are aimed at promoting specific values and beliefs; that is, investments that are determined by a conscious belief in the ethical self-worth of a particular action, and where less emphasis is placed on efficiency or financial utility maximization than is the case with the means-driven (zweckrational) perspective (ibid., p. 78). It is also important that such investment prioritizes 'the investee or beneficiary in terms of returns and often focuses on social (...) impact and social change' (ibid., p. 84). This type of revenue typically consists of conventional donations from private or public actors.

In order to also accommodate the investments that cannot be captured by Weber's two ideal types, Nicholls establishes a third category, a systemic investment rationale, which is a hybrid of the other two rationalities and offers the possibility that means-driven investments can also be based on the investor's value-based assessments.

The potential of Nicholls' model is that it provides a way of bringing together the exploration of different social finance rationalities within social finance. The value-driven rationale not only includes mutualism, but also represents a traditional way of operating based on philanthropy and 
humanitarian principles, whereby volunteers are generally motived by altruistic factors (Warburton et al. 2017). This is a tradition that is also based on personal relationships, methodological autonomy adapted to local conditions, and a lack of clear and compelling standards on best practise (Smith 2018). A number of studies find correlations between such conditions and favourable conditions for volunteers (Warburton et al. 2017; Frumkin and Kim 2002; Lie and Baines 2007).

The opposite would appear to be the case with revenue based on the means-driven rationale, which represents an entirely different set of values and narrative. Here, the focus is on performance and accountability. Financing is not obtained through relationships with stakeholders, but rather through competitive tenders. To be successful within this rational requires administrative infrastructure to monitor funds and programs as well as streamlined concepts for efforts. This more clinical and evidence-based way of working also involves the hiring of professional staff who are trained in a particular field. In some studies, this more regulatory environment is seen as a barrier to volunteering, since it conflicts with the "operating model" of volunteers who often exercise "craft knowledge," where effective practices are based on their own knowledge and interactions with clients (Schon 1983; Warburton 2018).

The strength of Nicholls' model is that the categories in the model are broad enough to be able to cover the entire spectrum of different forms of finance while at the same time capturing the rationales behind the instruments. This provides a more precise basis for analysis than analyses that only consider the source from which the income comes, such as private or public. However, parallel to the research-related potentials in Nicholls' model is also some significant weaknesses. First, the assumption that investment decisions can be placed unambiguously in one of three different archetypal rationales. The realities will often be "muddier," and the model may only capture the 
most essential rationale in a given income. Secondly, a number of potentially significant factors are not included in the model. This applies to both the importance of non-economic factors as well as macro-economic and sociological factors, which must be assumed to have an impact on the total number of volunteers.

Kendall et al. (2018) have investigated the importance of internal organisational and non-financial factors for strategic priorities within voluntary organisations. They argue that much of the past research studying non-profit organisations, including their involvement of volunteers, has focused too narrowly on the financial resources. Similarly, Chew and Osbourne (2008) and Chapman (2018) point out the risk of a too-narrow focus on the finances of voluntary organisations in terms of their long-term performance and robustness. In order to elucidate the importance of internal and nonfinancial factors in relation to the number of volunteers in this article, the significance of the age of the organisation and its equity are investigated in a separate regression-model, as these factors are assumed to be indicative of a measure of organisational capacity and stability.

Macroeconomic and sociological factors must also be assumed to have an impact on the ability of organizations to recruit volunteers. Thus, a number of Danish studies have found a positive correlation between the number of volunteers and employment, loose social networks and the general trust in society (Boje 2017; Fridberg and Henriksen 2014). In order to control for this influence, three variables have been included in all the models applied: the general development in employment; the use of the Internet as a proxy for loose networks and the general development in security and trust in the Danish population (Andersen et al. 2017). 


\section{Method}

The Danish population of nationwide non-profit social organizations included in the study is identified using the National Board of Social Services register of nationwide voluntary social nonprofit organizations. To be included in the register, the organizations must also be nationwide, which is defined as having activities in at least three of the five Danish regions.

In 2012, the population comprised of 76 organizations, a number that increased to 98 in 2017 . The total revenue together with the mix of public and private revenue calculated from the abovementioned register. In addition, accounts have been collected from the organizations for the period 2012-17. Accounts were received from 58\% of the organizations for the period 2012-14 and $71 \%$ for $2015-2017$. On average, the collected accounts represent $91 \%$ of the revenue in the total population. All figures are presented in 2017-Euro (€).

The revenues from public and private sources and the monetary value of the voluntary work are shown in figure 1 . This calculation is based on the number of volunteers and an estimation of their hours worked from the official national survey on volunteering in Denmark. The number of volunteers is calculated based on the annual accounts obtained directly from the organizations and supplemented with information from the Danish Institute for Voluntary Effort. The monetary value of the voluntary work is determined based on the principle quality adjusted replacement cost based on declared prices (Salamon 2010; Abraham and Mackie 2004). It has not been possible to get information about the specific nature of the work carried out by the volunteers throughout the period of investigation, and therefore not possible to use the specialist method (cf. The Handbook on Non-Profit Institutions in the System of National Accounts; United Nations 2018). Instead, the generalist method was used, which applies an hourly wage corresponding to the lower quartile for 
public service employees, which in Denmark amounted to $€ 20.7$. This pricing is more conservative than suggested in the UN Handbook (ibid.), which recommends an average wage that would be $€ 24.1$ (i.e. $17 \%$ higher).

The results of the three models described in the theory section are presented in Table 2 . The regression coefficients shown are calculated based on the number of volunteers each year in each organization in Denmark. Ideally, it would have been more expedient to use the number of hours worked by volunteers, since this would be a better indicator of the volunteers' commitment and, consequently, a more accurate estimate of the organizations' voluntary capacity. However, that kind of data has not been available to this study.

The accounting information is coded for standardized revenue types to compare the organizations over time. The coding according to Nicholl's investment logics and rationalities has been carried out as shown in table 1. As the information on the organization's income is coded from the combined sources, multi-collinearity between Nicholl's revenue variables and the mix of public and private sources of revenue is quite possible. The three models are therefore examined separately (see Table 2). 
Table 1 Coding of sources of revenue - Nicholl's investment rationalities

\begin{tabular}{|c|c|c|c|}
\hline Category & $\begin{array}{l}\text { Who mainly } \\
\text { defines the use of } \\
\text { the revenue? }\end{array}$ & $\begin{array}{l}\text { Sources of income from the } \\
\text { accounts }\end{array}$ & $\begin{array}{l}\text { Examples of sources of } \\
\text { revenue }\end{array}$ \\
\hline Means-driven & $\begin{array}{l}\text { Investor - } \\
\text { typically a fund, } \\
\text { state or } \\
\text { municipality }\end{array}$ & $\begin{array}{l}\text { Private, earmarked funds; private } \\
\text { other; sales to private persons; } \\
\text { sales to public sector; and other } \\
\text { public revenue }\end{array}$ & $\begin{array}{l}\text { 1. Earmarked grant to } \\
\text { specific project (e.g. debt } \\
\text { counselling) } \\
\text { 2. Revenue from the } \\
\text { provision of specific service } \\
\text { according to the Services } \\
\text { Act (e.g. payment for a } \\
\text { place at a women's crisis } \\
\text { shelter) }\end{array}$ \\
\hline Value-driven & $\begin{array}{l}\text { Receiving } \\
\text { organization }\end{array}$ & $\begin{array}{l}\text { Donations etc; membership dues } \\
\text { and personal contributions; interest } \\
\text { payments; other private; general } \\
\text { public support and gambling and } \\
\text { lottery revenues }\end{array}$ & $\begin{array}{l}\text { 1. General operating grant } \\
\text { on the Finance Act or from } \\
\text { a foundation } \\
\text { 2. Non-earmarked } \\
\text { contribution from private } \\
\text { persons. }\end{array}$ \\
\hline Systemic & Mixed & $\begin{array}{l}\text { Public grants earmarked to } \\
\text { innovative projects. }\end{array}$ & $\begin{array}{l}\text { 1: A project funded by the } \\
\text { Social Reserve Fund for the } \\
\text { development of specialized } \\
\text { treatment services }\end{array}$ \\
\hline
\end{tabular}

Source: Nicholls 2010 
The data set contains comprehensive information on revenue and the number of volunteers for each of the participating organizations for the period 2012-17. This is panel data, and a regression model with Panel Corrected Standard Errors (PCSE) cf. Beck and Katz (1995) and Beck (2001) has therefore been chosen. This choice is made because a pure Ordinary Least Square (OLS) model applied to panel data fails to account for the correlation between the organizations studied or between the time periods, thereby breaking with the assumptions in the model about independent and uniform distribution of variance.

An alternative would be to use a Fixed Effects (FE) model assuming homoscedasticity in the error terms. However, a Breusch-Pagan test revealed heteroscedasticity in the model, and it is, therefore, necessary to calculate corrected standard errors to obtain reliable tests of significance levels. Calculating corrected standard errors in the FE model implies that the standard errors will be up to four times higher due to the limited size of the dataset. The solution to this could be to increase N, but this is obviously not possible, as the entire population is a maximum of 98 organizations and because the organizations have been contacted twice for a response.

Instead, decision was made to use the PCSE model, which corrects for the correlation of the fault links and the resulting heteroscedasticity. Beck and Katz (1995, p. 638) test the PCSE coefficients relative to OLS in a Monte Carlo experiment with a randomly constructed panel data set. The test shows that in a high-heteroscedasticity data set, the PCSE model is always within $10 \%$ of the real variation. This is unlike OLS, which deviates by up to $44 \%$ under the same conditions. In order to engage the reader in the consequences of these choices pertaining to method, the coefficients from the OLS and the fixed effects models are shown in Appendix A. 


\section{The Danish case}

In this section, I start outlining some of the main features of the development in the Danish social non-profit sector as well as the composition and size of the studied population.

In the decades after World War II, there was a "crowding out effect" regarding the role of voluntary social organizations as service provider, as the state and municipalities took over the provision of the majority of welfare services due to the expansion of the welfare state (Wijkström 2011). As an alternative to the role of service provider, several voluntary organizations adopted political advocacy strategies, where the goal was to pressure the welfare state to take responsibility for dealing with the specific problems that the organizations' target groups were claimed to have (Henriksen and Bundesen 2004).

In the 1980-90s, a renewed interest in involving voluntary social organizations in social policy efforts appeared because the public supplier model had proven itself inadequate in a number of areas (Skalts and Nørregaard 1981). During the 1990s, specific financial support opportunities were established for local voluntary associations, although the financing conditions largely consisted of temporary (and thus uncertain) grants (Henriksen and Bundesen 2004; Ibsen 1997).

In the periods the $2000 \mathrm{~s}-2010 \mathrm{~s}$, the research on the state-civil society relationship characterizes Denmark as being driven by cooperation and openness as well as increased interest from changing governments for further involvement of the voluntary social sector in social policy initiatives (Lorentzen and Henriksen 2014; Wijkström and Zimmer 2011). This has made little difference, however, as the public sector delivers the majority of welfare services. Thus, $79 \%$ of the labour 
force within the welfare sector was employed in the public sector in 2013 , while $14 \%$ was employed in the non-profit sector and 7\% in commercial enterprises (Boje 2017; Sivesind 2016).

In the same period, both state and private foundations have had a sharper focus on the provision of services and raised requirements for increased documentation and impact assessments (Espersen et al. 2018). This has put an isomorphic pressure on the organizations in relation to targeting and professionalizing their efforts (Andersen 2019), which has triggered concerns about the ability to reduce the flexible and responsive element of volunteering, thereby leading to a fall in the number of volunteers (Henriksen et al. 2008). The percentage of the population engaged in volunteer work has been stable since 2000, at around 35\% (Fridberg and Henriksen 2014; Boje 2017).

The total population of nationwide non-profit social organizations in Denmark consists of 98 organizations, which together had a total revenue of $€ 0.95$ billion in 2017 . The organizations and their local chapters make up approximately $1 / 3$ of the total number of volunteers in the social sector. The size and revenue within this group vary considerably: one-quarter of the organizations have annual revenue of less than $€ 0.2$ million and half less than $€ 0.7$ million, whereas the annual revenue of the largest organization was $€ 420$ million in 2017. International development and aid work carried out by organizations operating nationwide, such as the Red Cross, accounts for $56 \%$ of the income in the sector; and this part of the revenue is excluded from the analysis. In the period $2012-17$, the total internal revenue increased by $34 \%,{ }^{1}$ while the number of volunteers in the organizations increased by $30 \%$ in the same period (from 62,664 persons to 81,262 ). There is a significant spread in the organisations' age and equity: in 2017 , the youngest organization was three

\footnotetext{
${ }^{1}$ Fixed prices have been used at the 2017 level.
} 
years old, whereas the oldest was established 154 years ago. The average equity in 2017 was $€ 4.4$ million, and the median was $€ 0.3$ million.

In 2012, the revenue from public and private sources was roughly equal, each amounting to slightly more than $€ 130$ million (cf. Figure 1). Throughout the period under investigation, the private revenue increased by $46 \%$, while the public revenue only increased by $22 \%$. The monetary value of the volunteers' efforts amounted to $€ 260$ million and increased over the course of the period by $12 \%$, corresponding to $€ 300$ million. That the value of the volunteers' efforts increases less than does the number of volunteers is due to the circumstance that the number of hours of volunteer work falls by $11 \%$. In 2017 , the monetary value of the voluntary contributions corresponded to $43 \%$ of the total financial framework, while the private and public revenue contributed, respectively, 30 $\%$ and $27 \%$.

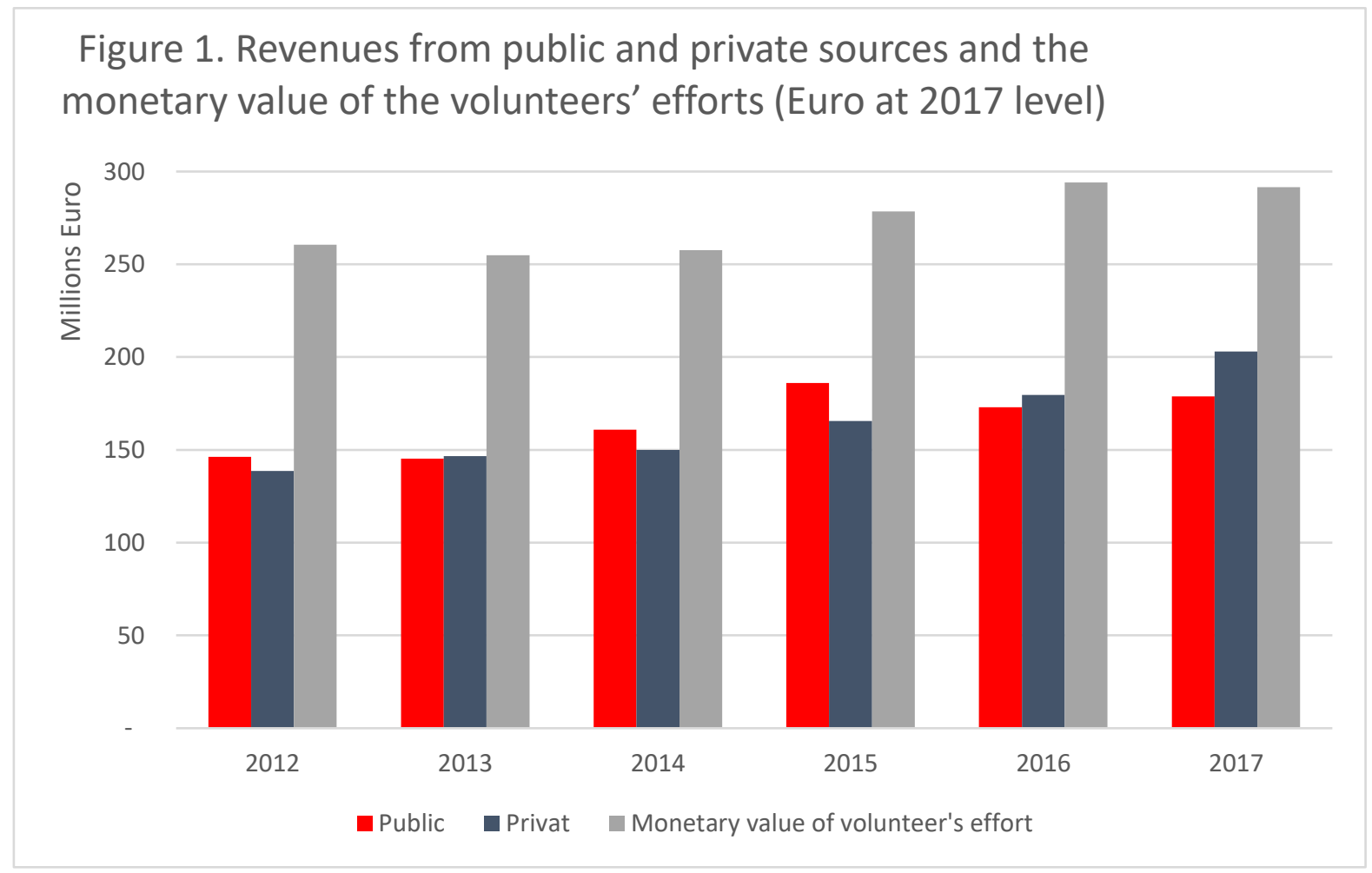

Source: The accounting database and own calculations 
In 2012, 57\% of the revenue among non-profit organizations was means-driven, $31 \%$ value-driven, and $12 \%$ systemic. The total distribution for the period is illustrated in Figure 2. While the meansdriven (zweckrational) sources of revenue increased over the course of the period by $€ 37.6$ million, its relative importance fell due to a sharp increase in the value-driven revenue, which increased by $72 \%$ in the same time, corresponding to a $€ 66.5$ million increase. The increase is mainly due to significant growth in private donations to the organizations. There was a slight downward trend in the systemic investments.

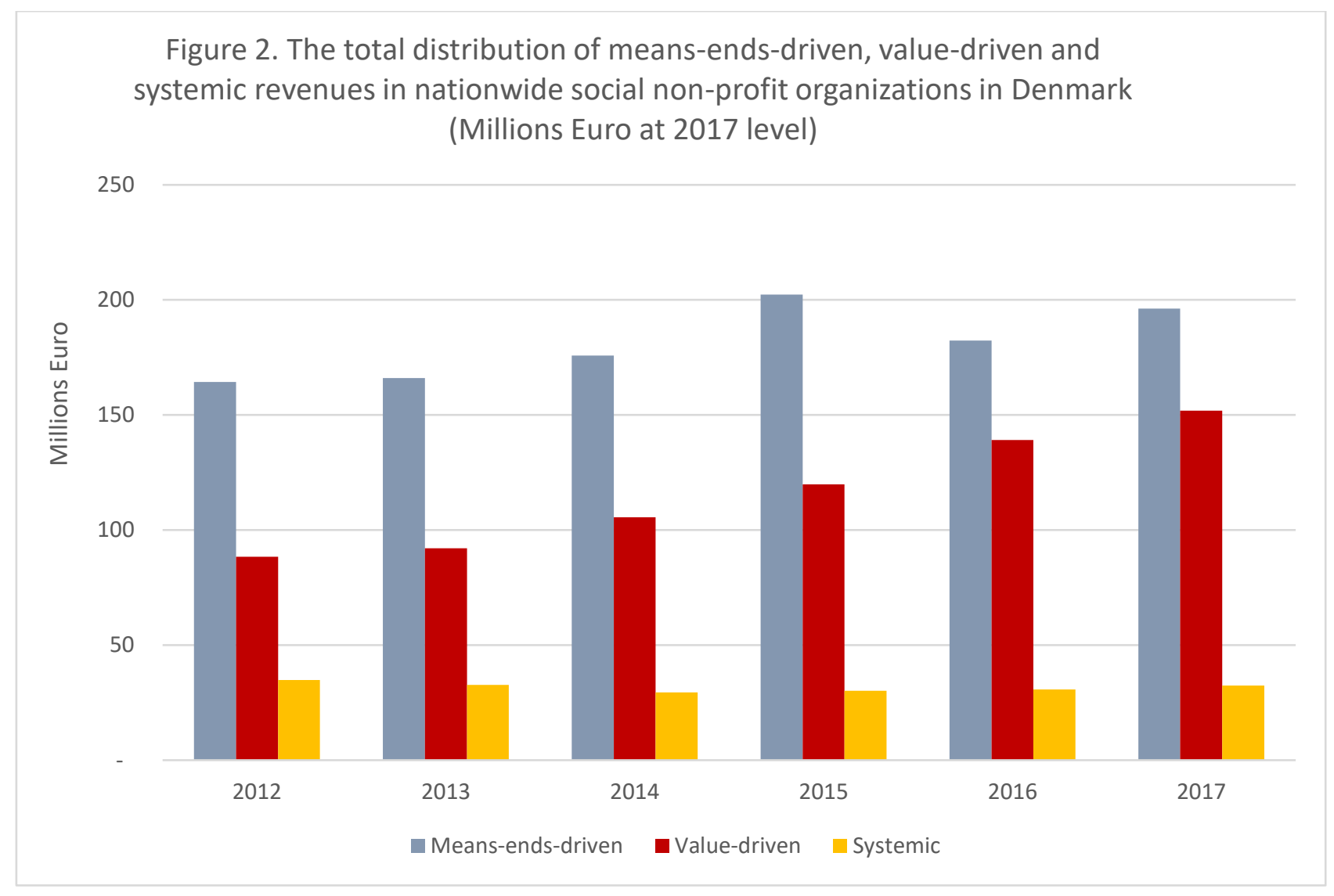

Source: The accounting database and own calculations

\section{Association between funding and number of volunteers}

The purpose of this article is to gain a better understanding of the relationship between the type of financing of non-profit organizations and the number of volunteers in the organizations. In the theory section, it was also argued that it would be relevant to shed light on whether the number of 
volunteers is affected by internal and non-financial factors as well as social factors which, in other studies, have been shown to have impact on the general number of volunteers.

In particular, I set out to test three models and their effect on the number of volunteers. The first examines the importance of internal and non-financial conditions in terms of equity and the age of the organization. The second investigates the significance of public and private revenue in relation to the number of volunteers. The third model examines the correlations between different investment rationales, as defined by Nicholls (2010).

The results are presented in Table 2. The first column is the results of the modelling of the internal, non-economic conditions. The coefficient for equity is 28.99 , and thus positive and statistically significant at the 0.001 level. The interpretation of this estimate is that an increase in equity at $€ 0.1$ million correlates to an increase of 28.99 volunteers. The coefficient for the age of the organization is -106.1 , and the model thus reveals a negative, modest, statistically significant at the 0.05 level. The interpretation of this estimate is that an organization will lose an average of 106 volunteers per year. Although equity is often in bricks and mortar, it can also be viewed as an indication of organizational stability. Thus, the results suggest that internal, as well as non-financial factors, have a significant impact on the number of volunteers.

The positive significance of equity can be interpreted in the sense that stability and organizational capacity are favourable conditions for a high number of volunteers. The negative significance of age points in the direction of the growth in the number of volunteers not being solely an organic process and a function of the age of the organization; rather, it is subject to managerial choices and 
actions. Alternatively, the context can also be seen as an indication that some organizations become more professional over time and therefore use volunteers less.

Table 2: Influence from internal factors and different revenue streams and investment rationalities on the number of volunteers

(Coefficients, standard errors and significance levels: $*_{\mathrm{p}}<0.05$; **p $<0.01$; ***p $<0.001$. Revenues in Euro)

\begin{tabular}{lc}
\hline \multicolumn{1}{c}{ Variable } & Internal factors \\
\hline Equity & $\mathbf{2 8 . 9 0 ^ { * * * }}$ \\
& 2.82 \\
& $\mathbf{- 1 0 6 . 1 0}^{*}$ \\
Org. age & 46.69
\end{tabular}

Private

$24.55^{* *}$

6.23

Public

$3.46^{* * *}$

0.54

Means-ends

1.15

1.81

Value-based

32.08**

11.67

Systemic

$19.80^{* *}$

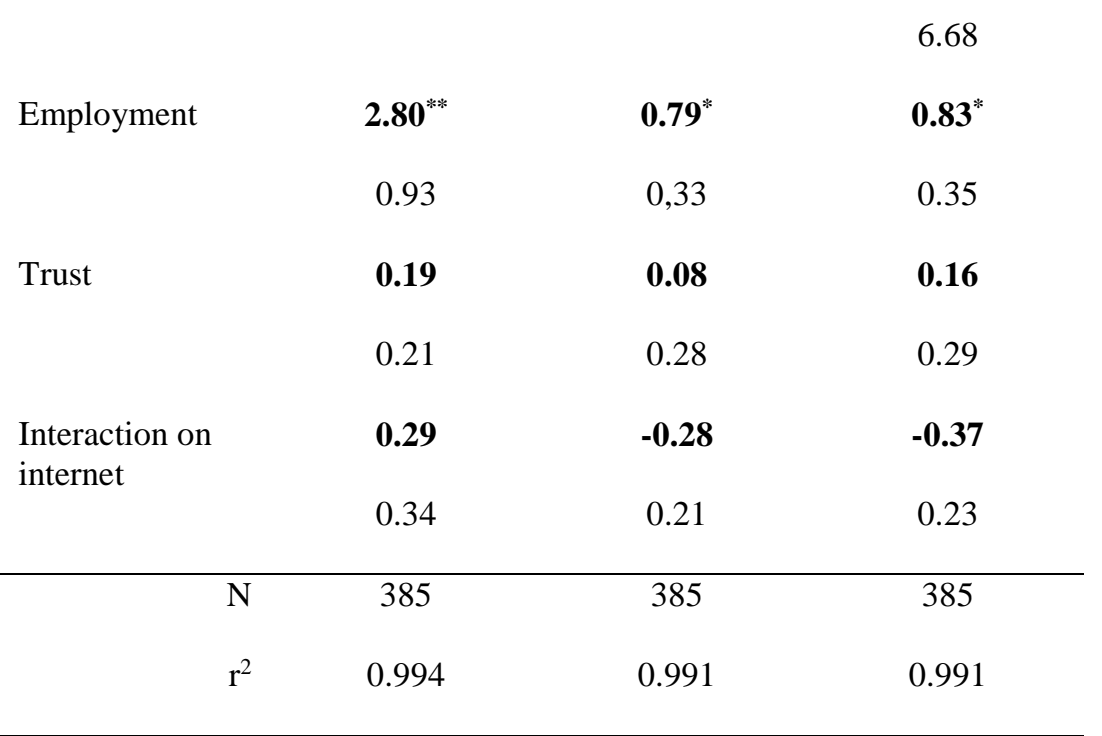


In model for public and private revenue, we see how the coefficient for private revenue streams is 24.55 , positive and statistically significant at the 0.01 level. The coefficient from the public revenue is less and amounts to a modest 3.36 , but positive and significant at the 0.001 level. The interpretation of this estimate is that a $€ 0.1$ million increase in private revenues is expected to correspond to an increase of almost 25 volunteers, while a similar increase in public revenues will result in three more volunteers.

The main sources of private income are donations (49\%), sales from second-hand stores, which provides unrestricted revenue (29\%), and earmarked projects (13\%). This positive relationship should be no surprise if one believes that unrestricted revenues from donations and sales create flexible organizations and thus favourable conditions for having many volunteers. Public revenue and the number of volunteers also have a significant, albeit weak, positive relationship. Here, the main sources are the sale of services (66\%), specific projects (14\%), and general support (13\%). These are completely different types of income which have nothing in common other than the fact that they come from the public sector, and this estimate should therefore be interpreted with considerable caution.

The third model illustrates Nicholls' investment rationales. The coefficient of means-driven income is 1.15 but not statistically significant. The coefficients for value-based and systemic revenues are, respectively, 32.08 and 19.80; both thus positive and statistically significant at the 0.01 level. The interpretation of this estimate is that we are not able to say anything about the impact of meansends revenues, whereas an increase in value-based or systemic revenues at $€ 0.1$ million should result in, respectively, 32 and 20 more volunteers. The non-significant coefficient from the meansdriven revenue is a surprising finding. One way of interpreting this result is to recognize that it does 
not support the idea that professionalization causes devoluntarization. The other side of the coin is that the coefficients of the value-based revenues are both statistically significant and fairly high compared to the other estimates. This seems to indicate that more volunteers can be secured if value-based revenues increase. Here, a possible interpretation might be that volunteers can easily contribute to specialized efforts, but an increase in the number of volunteers requires sources of revenue and thereby organizational forms that are more open and not tightly goal-oriented.

In order to control for the influence of some macroeconomic and sociological factors that in some Danish studies had proven to have a significant correlation with the overall number of volunteers, three variables were included in all the models applied: the general development in employment; the use of the Internet as a proxy for loose networks and the general development in security and trust in the Danish population. As shown in table 2, there are positive and significant coefficients for the correlation between the development in general employment and the number of volunteers in the surveyed nationwide organizations. The interpretation of these estimates is that an increase in employment of 1,000 people is correlated with an increase of 3 volunteers. The coefficients for trust are not statistically significant, which we otherwise expected, which might be due to the fact that trust and security have had a slightly declining trend in Denmark, while the surveyed organizations have managed to increase the number of volunteers significantly. The coefficient for the interaction on the Internet is not statistically significant. However, this variable is neither a perfect proxy for measuring lose ties, which in some Danish research has been found to have a significant and positive correlation with volunteering. 


\section{Conclusion}

The relationships between funding and the number of volunteers is a contested field. On the one hand, there are arguments and concrete examples illustrating that more specific and competitive funding changes the organizations' ethos from informal and often smaller organizations to larger, more formalized organizations that work clinically and evidence-based. This more professional operating model does not harmonize well with the use of volunteers, who typically are characterized with craft knowledge and personal relationships. Therefore, this type of funding has a negative impact on the number of volunteers. On the other hand, it is argued that increased bureaucratization is a natural consequence of modernization, and there is not necessarily any contradiction between having a flexible organization and attracting volunteers. What the type of financing means for the organizations primarily depend on the managerial priorities and actions.

In this article, I have sought to investigate the issue analysing panel data on nationwide non-profit organizations in Denmark. The conclusions must be interpreted with caution. Denmark is obviously neither England, USA nor Australia, and it is from these countries that most research in this area originates. The Danish non-profit organizations are characterized by having a modest and supplementary role in the overall welfare production, which is markedly different from the AngloAmerican countries In Denmark, there has been an increase in financing with requirements for performance management, and thereby also tendencies towards increased formalization and professionalization of non-profit organizations. At the same time, however, it is probably also a fair assessment that the implementation has taken place in an environment characterized by more trust and less competition in the NGO sector than what can be observed in England. As a result of this more soft implementation, the consequences of the new elements in financing may be more subdued in Denmark than will be apparent in other welfare regimes. 
With the above reservations in mind, my main finding is that there is an association between different types of financial instruments and the number of volunteers. This connection was found in the 'traditional' model, where the organizations' income is divided according to whether they come from private or public sources. The more free private funding had a strong and positive correlation to the number of volunteers. A positive (albeit weaker) significance could also be found between public revenue and the number of volunteers. However, it is difficult to conclude about the impact of government funds, as this category contains many different types of funding - from general grants to specific contracts for specific supplies.

In an attempt to find an analytical instrument that is more accurate than the public /private perspective, I used Nicholls' financing rationales. The idea behind the Nicholls model is that, based on the rationales, it paints a clearer picture of the different types of financing. This perspective confirmed the positive and significant correlation between (unrestricted) funding and the number of volunteers. Systemic income for innovation also correlated positively with the number of volunteers. On the other hand, no statistically significant correlation is seen between means-ends funding types of financing and the number of volunteers. In the Danish context, the hypothesis regarding devoluntarization as a result of increased demands for formalization and professionalization can therefore not be confirmed.

Another finding was that a number of internal and non-financial factors also have a significant effect on the number of volunteers. Equity was used as a proxy for the stability and capacity of the organizations, and a strong and positive correlation was found here. This indicates that investments in organizational capacity have a positive correlation with the number of volunteers. Similarly, the importance of managerial choices and actions was indirectly confirmed through the finding that the 
age of the organizations - ceteris paribus - has a significant negative correlation with the number of volunteers. The finding further emphasized the significance of the financial factors that societal factors such as the general development in employment also has a significant and positive correlation with the number of volunteers in the organizations surveyed.

A number of research perspectives must also be mentioned. My scientific approach implies that, in principle, I consider all models to be incorrect, but at the same time acknowledge that some models may be useful. Nicholls' model qualifies the relation between type of investments and the use of volunteers, through a focus on rationalities. It contributes to more nuanced images on the importance of financing compared to analyses that are 'merely' based on whether the sources of revenue are public or private. However, three adjustments could improve the model and the use of the model. First, newer studies find that the perception of volunteering and policy climate impacts the number of volunteers (Kendall et al 2018). Consequently, incorporating non-financial factors like these would improve the model. Second, a technical improvement would be to base the model on hours delivered by volunteers instead of a headcount. Data like this is hard to achieve but would make more accurate estimations of the organizations' voluntary capacity. Third, knowledge about the volunteers' tasks could be relevant, whereby it could be elucidated whether the funding contributes to changes in the voluntary task mix. For example, if volunteers are given more administrative tasks as a result of more administratively demanding forms of financing.

In a broader perspective, future research should consider segmentation of the analyzed organizations since the literature points in the direction that smaller and more grass-rooted orientated organizations find it harder to apply the means-driven income sources' requirements. This perspective could also be fruitful outside the science world for practitioners and investors 
searching for the right instrument to the right purpose. In addition to this, an international comparative perspective could bring about more nuances of the findings, exploring the impact of different welfare regimes and the variation in how the financial instruments are implemented. 
Appendix 1: Influence from internal factors and different revenue streams and investment rationalities on the number of volunteers

(Coefficients, standard errors and significance levels: *p < 0.05; **p <0.01; ***p < 0.001. Revenues in Euro)

\begin{tabular}{|c|c|c|c|c|c|c|}
\hline \multirow[t]{2}{*}{ Variable } & \multicolumn{2}{|c|}{ Internal factors } & \multicolumn{2}{|c|}{ Public/private } & \multicolumn{2}{|c|}{ Rationalities (Nicholls) } \\
\hline & OLS & Fixed effects & OLS & Fixed effects & OLS & Fixed effects \\
\hline Equity & $\begin{array}{c}\mathbf{2 8 . 9 3}^{* * *} \\
3.80\end{array}$ & $\begin{array}{c}\mathbf{2 8 . 9 0}^{* * * *} \\
1.45\end{array}$ & & & & \\
\hline Org. age & $\begin{array}{r}-4.99 \\
6.83\end{array}$ & $\begin{array}{r}\mathbf{- 1 0 6 . 1 0} \\
141.12\end{array}$ & & & & \\
\hline Private & & & $\begin{array}{c}91.13^{* * *} \\
1.57\end{array}$ & $\begin{array}{r}\mathbf{2 4 . 5 5} \\
15.8 *\end{array}$ & & \\
\hline Public & & & $\begin{array}{l}\mathbf{1 . 5 7} \\
0.99\end{array}$ & $\begin{array}{c}3.46^{* * *} \\
1.24\end{array}$ & & \\
\hline Means-ends & & & & & $\begin{array}{c}-\mathbf{7 . 8 8} \\
2.01 * *\end{array}$ & $\begin{array}{l}\mathbf{1 . 1 5} \\
1.01\end{array}$ \\
\hline Value-based & & & & & $\begin{array}{c}\mathbf{1 3 1 . 5 9}^{* * *} \\
5.99\end{array}$ & $\begin{array}{c}\mathbf{3 2 . 0 8}^{* * *} \\
3.83\end{array}$ \\
\hline Systemic & & & & & $\begin{array}{c}\mathbf{5 7 . 2 8}^{* * *} \\
12.15\end{array}$ & $\begin{array}{c}19.80^{* * *} \\
3.58\end{array}$ \\
\hline Employment & 0.80 & 2.80 & -1.10 & $\mathbf{0 , 7 9}$ & -1.23 & $\mathbf{0 , 8 3}$ \\
\hline & 5.95 & 2.79 & 2.88 & 0.55 & 3.51 & 0.67 \\
\hline Trust & -0.12 & 0.19 & -0.71 & 0.08 & -0.24 & 0.16 \\
\hline & 5.27 & 0.48 & 2.55 & 0.60 & 3.10 & 0.59 \\
\hline Interaction on & -0.06 & 0.29 & 0.06 & -0.28 & -0.32 & -0.37 \\
\hline & 3.98 & 0.99 & 1.92 & 0.21 & 2.34 & 0.45 \\
\hline $\mathrm{N}$ & 385 & 385 & 385 & 385 & 385 & 385 \\
\hline $\mathrm{r}^{2}$ & 0.15 & 0.57 & 0.80 & 0.32 & 0.71 & 0.34 \\
\hline
\end{tabular}




\section{References}

Abraham, K. G., \& Mackie, C. (2004). Beyond the market: Designing nonmarket accounts for the United States. National Academies Press.

Aiken, M., \& Harris, M. (2017). The 'hollowing out' of smaller third sector organisations? Voluntary Sector Review, 8(3), 333-342.

Alcock, P. (2016). The history of third sector service delivery in the UK. In J. Rees \& D. Mullins (Eds.), The third sector delivering public services. Bristol University Press, Policy Press.

Andersen, J., Hede, A., \& Andersen. J. G. (2017). Tilliden til samfundets bærebjælker [Confidence in the pillars of society]. Copenhagen: Tryg Foundation.

Andersen, L. L. (2019). Hybride civilsamfundsorganisationer under forandring: Neoliberale praksisser, marked og civile rettigheder [Hybrid civil society organizations under change: Neoliberal practices, market and civil rights]. Tidsskrift for Arbejdsliv, 21(4), 67-75.

Baines, S., Hardill, I., \& Wilson, R. (2011). Introduction: Remixing the economy of welfare? Social Policy and Society, 10(3), 337-339.

Beck, N. (2001). Time-series-cross-section data: What have we learned in the past few years? Annual Review of Political Science, 4(1), 271.

Beck, N., \& Katz, J. N. (1995). What to do (and not to do) with time-series cross-section data. The American Political Science Review, 100(4), 67-67. 
Bernstein, S. (1991). Managing contracted services in the nonprofit agency. Temple University Press.

Body, A. (2015). Weathering the storm: Understanding the voluntary sector through a fields theory analysis: Early findings of a case study of preventative children's services in Kent. Working paper presented at Voluntary Sector and Volunteering Research Conference, NCVO, Leeds.

Boje, T. P. (2017). Civilsamfund, medborgerskab og deltagelse [Civil society, citizenship and participation]. Copenhagen: Hans Reitzels.

Chapman, T. (2017) Journeys and destinations: using longitudinal analysis to explore how third sector organisational governance helps to navigate sustainable futures. Voluntary sector review. [Online] 8 (1), 324.

Chew, C., \& Osborne S. P. (2008). Strategic positioning in UK charities that provides services. Public Money \& Management, 28(5), 283-290.

Clifford, D., Geyne-Rahme, F., \& Mohan, J. (2013). Variations between organisations and localities in government funding of third-sector activity: Evidence from the national survey of third-sector organisations in England. Urban Studies, 50(5), 959-976.

Espersen, H. H., Andersen, L. L., Olsen, L., Tortzen, A. (2018). Understøttelse og udvikling af det frivillige sociale arbejde [Support and development of voluntary social work]. Copenhagen: VIVE - The Danish Center for Social Science Research.

Fridberg, t, \& Henriksen, L. S. (2014). Udvikling i frivilligt socialt arbejde [Development in voluntary social work]. Copenhagen: SFI. 
Frumkin, P., \& Kim, M. T. (2002). The effect of government funding on nonprofit administrative efficiency: An empirical test. Cambridge, MA: Ash Institute for Democratic Governance and Innovation, John F. Kennedy School of Government, Harvard University.

Gronbjerg, K. A. (1991). Managing grants and contracts: The case of four nonprofit social service organizations. Nonprofit and Voluntary Sector Quarterly, 20(1), 5-24.

Henriksen, L. S., \& Bundesen, P. (2004). The moving frontier in Denmark: Voluntary-state relationships since 1850. Journal of Social Policy, 33(4), 605-625.

Henriksen, L. S., Koch-Nielsen, I., \& Rosdahl, D. (2008). Formal and informal volunteering in a Nordic context: The case of Denmark. Journal of Civil Society, 4(3), 193-209.

Ibsen, B, (1997). Fordærver pengene foreningerne? [Does money corrupt associations?] Politica, 29(1), 49.

Ishkanian, A., \& Szreter, S. (2012). The big society debate: A new agenda for social welfare? London: Edward Elgar.

Kendall, J., Mohan, J., Brookes, N., \& Yoon, Y. (2018). The English voluntary sector: How volunteering and policy climate perceptions matter. Journal of Social Policy, 47(4), 759-782.

Kramer R. M. (1994). Voluntary agencies and the contract culture. Social Service Review, 68(1), 33-60.

Lie, M., \& Baines, S. (2007). Making sense of organizational change: Voices of older volunteers. Voluntas, $18(3), 225-240$. 
Lorentzen, H., \& Henriksen, L. S. (2014). The invention and institutionalization of volunteer centers: A comparative analysis of Norway and Denmark. Nonprofit and Voluntary Sector Quarterly, 43(3), 589-608.

Milbourne, L. (2013). Voluntary sector in transition: Hard times or new opportunities? Bristol: Policy Press.

Milbourne, L., \& Murray, U. (2017). Civil society organizations in turbulent times: A gilded web? London: Trebtham Books.

Milbourne, L., \& Murray, U. (2017B). Dangerous liaisons and spaces for resistance. In Civil Society Organizations in Turbulent Times: A Gilded Web? London: Trebtham Books.

Mulgan, G. (2015). Social finance: Does 'investment' add value? In Nicholls et al. (Eds.), Social finance (pp. 45-64). Oxford University Press.

Murray, U. (2017). Voluntary organizations and criminal justice: A misguided turn. In L. Milbourne \& U. Murray (Eds.), Civil society organizations in turbulent times: A gilded web? London: Trebtham Books.

Nicholls, A. (2010). The institutionalization of social investment: The interplay of investment logics and investor rationalities. Journal of Social Entrepreneurship, 1(1), 70-100.

Nicholls, A. et al. (2015). Social Finance. Oxford University Press.

Nicholls, A., \& Emerson, J. (2015). Social finance: Capitalizing social impact. In A. Nicholls et al. (Eds.), Social finance (pp. 1-45). Oxford University Press.

Pharoah, C. (2012). Finding the big society. In A. Ishkanian \& S. Szreter, see above. 
Salamon, L. (2010). Putting the civil society sector on the economic map of the world. Annals of Public and Cooperative Economics, 81(2), 167-210.

Salway. M. (2017). Social investment as a new charity finance tool: Using both head and heart. Centre for Charity Effectiveness, Cass Business School; University of London.

Schon, D. (1983). The reflexive practioner: How practitioner think in action. New York: Basic.

Sivesind, K. H. (ed.) (2016). Mot en ny skandinavisk velferdsmodell? [Toward a new Scandinavia welfare model?]. Institut for samfundsforskning, rapport 2016:01.

Skalts, V., \& Nørgaard, M. (1981). Mфdrehjcelpens epoke [The era of Mothers' Aid]. Copenhagen: Forlaget Rhodos.

Smith S. R. (2018). The future of nonprofit human services. Nonprofit Policy Forum, 8(4), 369-389.

United Nations (2018). Handbook on non-profit institutions in the system of national account. New York: Department of Economic and Social Affairs Statistics Division.

Young, D. (2015). Financing social innovation. In Nicholls et al. (Eds.), Social finance (p. 96-112). Oxford University Press.

Warburton J., Moore M., \& Oppeinhemer M. (2018). Challenges to the recruitment and retention of volunteers in traditional nonprofit organizations: A case study of Australian meals on wheels. International Journal of Public Administration, 41(16), 1361-1373.

Weber, M. (1978). Economy and society: An outline of interpretive sociology. Berkeley University of California Press. 
Whitfield, D. (2014). The ideological context. NCIA Inquiry into the Future of Voluntary Services.

Wijkström, F. (2011). Charity speak and business talk: The on-going (re)hybridization of civil. In Nordic civil society at a cross-roads: The transformation of the popular movement tradition. Nomos.

Wijkström, F., \& Zimmer, A. (2011). Introduction: Nordic civil societies beyond. In Nordic civil society at a cross-roads: The transformation of the popular movement tradition. Nomos. 